\title{
Phenotype and intellectual development variability in family with Pfeiffer Syndrome caused by p.P252R mutation in FGFR1 gene
}

\section{Wewnątrzrodzinna zmienność fenotypu i rozwoju intelektualnego w zespole Pfeiffera wywołana mutacją p.P252R w genie FGFR1}

\author{
Anna Jakubiuk-Tomaszuk', Wojciech Sobaniec ${ }^{1}$, Beata Olchowik ${ }^{1}$ \\ ${ }^{1}$ Department of Pediatric Neurology and Rehabilitation, Medical University of Białystok
}

\section{STRESZCZENIE}

Zespół Pfeiffera (OMIM\#101600) jest rzadkim zespołem uwarunkowanym genetycznie zaliczanym do dysostoz czaszkowo-twarzowych, który dziedziczy się w sposób autosomalnie dominujący ze zmienną ekspresją cech klinicznych. Występuje z częstością około 1:100 000 wśród żywo urodzonych dzieci. Typowe objawy zespołu obejmują: przedwczesne zarastanie szwów czaszkowych (kraniosynostoza), hipoplazja szczęki oraz wady dłoni i stop. Objawy zespołu Pfeiffera wywołują heterozygotyczne mutacje w genach czynnika wzrostu fibroblastów typu 1 lub 2 (fibroblast growth factor receptor gene type 1 or 2 - FGFR1 lub FGFR2). Mutacje występujące w genie FGFR1 skutkują mniej nasilonymi objawami fenotypowymi twarzoczaszki, wadami kończyn i najczęściej prawidłowym rozwojem intelektualnym. W niniejszej pracy autorzy przedstawiają trzy przypadki z jednej rodzinny (syn, ojciec i córka) prezentujące dużą zmienność objawów fenotypowych i intelektualnych w przebiegu zespołu Pfeiffera typu 1 wywołanego mutacją p.P252R w genie FGFR1. Autorzy zwracają uwagą na celowość wykonywania badań rodzinnych w kontekście diagnostyki niepełnosprawności intelektualnej i poradnictwa genetycznego.

Słowa kluczowe: kraniosynostoza, wady kończyn, niepełnosprawność intelektualna, gen FGFR1
ABSTRACT

Pfeiffer Syndrome (OMIM\#101600) is a genetic disorder which belongs to cranio-facial dysostosis group inherited in an autosomal dominant pattern with variation of feature expression. It affects about 1 in 100,000 live-births. Typical features include: premature fusion of certain bones of the skull (craniosynostosis), maxillary hypoplasia and digital abnormalities of the hands and feet. Basing on the phenotype three clinical subtypes of Pfeiffer Syndrome can be distinguished: types 1, 2 and 3 . This condition can be caused by heterozygous mutations in either fibroblast growth factor receptor gene type 1 or 2 (FGFR1 or FGFR2). FGFR1 mutations often result in less severe craniofacial involvement, no craniosynostosis, abnormalities of the limbs and most individuals have normal intelligence. The authors describe the family of three members (a son, a father and a daughter) variably affected by phenotype and intellectual development with Pfeiffer Syndrome type 1 caused by p.P252R mutation in FGFR1 gene.

We showed that in investigating mental retardation the medical examination of the whole family and genetic counseling are important.

Key words: craniosynostosis, limb deformities, intellectual disability, gene FGFR1

\section{INTRODUCTION}

Pfeiffer Syndrome (OMIM\#101600) (Synonyms: Noack's, Pfeiffer and Martsolf, Martsolf-Reed Hunter, acrocephalosyndactyly IV, acrocephalosyndactyly $\mathrm{V}$ according to McKusick) is a group of craniofacial dysostosis inherited in an autosomal dominant pattern with variation of feature expression. This Syndrome was described for the first time in 1964 by German geneticist Rudolf Pfeiffer. It affects about 1 in 100,000 live newborn children [1]. In Pfeiffer Syndrome abnormal premature fusion of the sutures leading to brachycephaly, midfacial hypoplasia, ocular hypertelorism and prominence of the eyes occur. The thumbs and big toes are broad and deviated away from the other digits and syndactyly of the digits occurs. Rare additional signs may include contracture of the ulnar joint and synostosis of the radial-ulnar joint [2]. In separate cases and familial cases vast variations of expressions have also been described [1].
Basing on the phenotype three clinical subtypes of Pfeiffer Syndrome can be distinguished:

- Type 1 „classic” involves brachycephaly, midfacial hypoplasia, hand and feet abnormalities, and normal intellectual development.

- Type 2 where characteristic cloverleaf-shaped head can be observed, extreme proptosis, hand and feet abnormalities, elbow ankylosis and synostosis with mental retardation.

- Type 3 softer than type 2 with absence of cloverleaf shaped head [2].

The features of Pfeiffer Syndrome are caused by mutations in fibroblast growth factor FGFR1 gene (on chromosome 8p11.2-p11) and FGFR2 (on chromosome 10q26). Mutations within FGFR1 give milder craniofacial as well as decreased hand and feet symptoms [3, 4]. Pfeiffer 
Syndrome belongs to FGFR-Related Craniosynostosis Syndromes including other disorders: Apert syndrome, Crouzon syndrome, Beare-Stevenson syndrome, FGFR2related isolated coronal synostosis, Jackson-Weiss syndrome, Crouzon syndrome with acanthosis nigricans (AN), and Muenke syndrome $[5,6,7]$.

In this paper we present a 15 -years-old boy with mental retardation, as well as his father and sister, all displaying a high variation of variable phenotypes of Pfeiffer Syndrome and sharing the p.P252R mutation in gene FGFR1.

\section{CASE REPORTS}

Patient 1. 15 year-old boy (proband) was born at term from first pregnancy at $40^{\text {th }}$ week. Delivery was prolonged, complicated and instrumentally assisted. His parents were both young, not consanguineous with unremarkable family history. He weighed $4.35 \mathrm{~kg}$ (97 centile), was $59 \mathrm{~cm}$ (97 centile) long and had a head circumference of $38 \mathrm{~cm}$ ( $>97$ centile). The patient's Apgar score was 8 at the $1^{\text {st }}$ as well as the $5^{\text {th }}$ minute. Physical and motor developments were delayed. He gained the ability to sit on his own in the 12th month, was able to walk at the age of 1 year and 8 months. Speech development was significantly delayed and he started to say his very first words at 8 . He started to indicate his physiological needs at 10 . Since early childhood he has displayed autoaggressive behavior, bites and tears apart the dorsal side of his hand, plucks the umbilicus and behaves aggressively towards his caretakers.

Physical examination at the age of 15 showed normal physical parameters. His weight was $52 \mathrm{~kg}$ (25-50 centile), height was $174 \mathrm{~cm}$ (50 centile) and the head circumference was $56 \mathrm{~cm}$ (centile). The phenotype presented brachycephaly, flat occiput, low hairline, upslanting palpebral fissures, hypoplastic nose wings, high palate, protruding ears, thickened, horny dorsal skin of both hands, broad metacarpals, broad interphalangeal joints, prominent digit pads, big toes slightly deviated toward the middle, syndactyly between the second and fourth toes (Fig. 1a, d, g, j).

The proband was diagnosed with intellectual disability of a significant degree. Computer tomography of the head performed at the age of 3 showed a single tiny high attenuation area near the quadrigeminal cistern at the right side responsible for calcification. Magnetic resonance imaging performed at the age of 6 presented tiny cysts in both angles of posteriors associated with underdeveloped choriod plexus. No abnormalities were found in the ultrasonic scan of the heart and abdominal organs.

Examination of the whole family found that the proband's father (patient 2) had the following features: broad scull, brachycephaly, ptosis, small nose, low nasal bridge, midfacial hypoplasia, deep set eyes, hypertelorism, broad and rigid thumbs, broad big toes deviated toward the middle, partial syndactyly between the second and third toes (Fig. 2b, e, h, k). Intellectual development was normal.

The proband's 11-year-old sister (patient 3) showed slight clinical features such as broad and rigid thumbs, big toes slightly deviated toward the middle, partial syndactyly between the second and third toes (Fig. 3). Her intellectual development was normal.
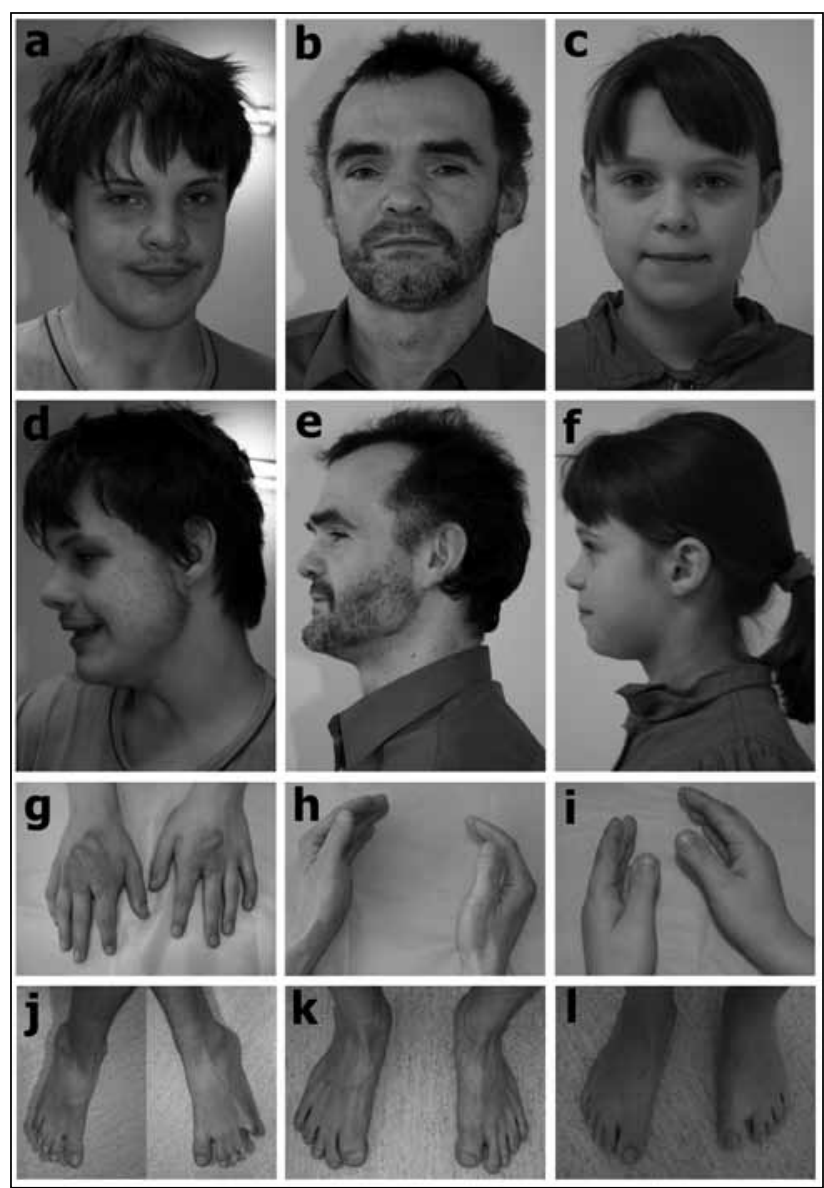

Fig. 1. A-f. Facial appearance of the three patients demonstrating hypertelorism, ptosis, midfacial hypoplasia particulaty marked in patient 2; $\mathrm{g}-\mathrm{i}$. Hands of the three patients showing broad and rigid thumbs in patients 2 and 3 ; j-l, feet of the three patients showing partial cutanaeous syndactyly 2-4 in patient 1, cutanaeous syndactyly 2-3 and broad big toes deviated towards the middle marked in patient 2.

The proband's karyotype was 46,XY. The parent's and sister's karyotypes were both normal. The boy's FRAX Syndrome test was negative. The FGFR1 gene p.P252R mutation was found in the boy as well as in his father and sister.

\section{DISCUSSION}

The presented 3-member family with Pfeiffer Syndrome shows the variety of different symptoms within the hands, feet, the presence or lack of discrete features of craniosynostosis and variable intellectual development.

Premature fusions of coronal and lambdoid sutures lead to differently expressed skull deformations. The characteristic skull phenotype with the presence of disproportionate wide skull with flat occiput, full high forehead, midfacial hypoplasia, small nose with low nasal bridge and ocular hypertelorism are present. Due to very shallow orbits, ocular proptosis is present [1]. The characteristic features of Pfeiffer Syndrome are broad medially deviated big toes, syndactyly between the second and fifth toes and wide sandal gap [8]. Broad medially deviated big toes and rigidity with no flexion in the interphalangeal joint, slightly 
broader thumbs were observed in the proband's father as well as sister. The abovementioned features were not reported in the proband. The roentgenograms of the hands showed osseous protuberance of the proximal phalanges. Saldino at al. [9] observed in their two patients fusion of the interphalangeal joints with an anomalous ossification center at the distal end of the proximal phalanx of the thumb. Thorough medical examination of the whole family, especially of proband's father's phenotype, suggested craniosynostosis research.

Rossi at al. [8] suggest that only the presence of feet anomalies without craniosynostosis indicates the need to carry out p.P252R mutation analysis of the FGFR1 gene. Our family cases suggested to take into consideration molecular genetic testing of p.P252R in the gene FGFR 1 in individuals referred for clinical genetic with symptoms within the hands and feet and without craniofacial anomalies. Mutation of p.P252R (Pro252Arg) in the FGFRI gene found in the presented family is responsible for $60 \%$ of Pfeifer Syndrome craniosynostosis identification. It is associated with the milder phenotype occurrence. Either FGFR1 or FGFR2 mutations cause type 1 Pfeiffer Syndrome.

Family cases of Pfeiffer Syndrome were reported only in patients with p.P252R mutation of the FGFR 1 gene but FGFR2 gene mutations cause type 2 or type 3 of Pfeiffer
Syndrome as a result of de novo mutations $[3,8,10]$. It was impossible to continue further investigation of the family, including examination of the proband's father's parents. The autosomal dominant pattern of inheritance indicates a $50 \%$ chance of Pfeiffer Syndrome in the affected person's children [1].

The proband's syndactyly between the second and fourth toes along with intellectual disability are not the typical spectrum of Pfeiffer Syndrome type 1 features. Chromosomal aberrations and FRAX Syndrome as the most frequent causes of intellectual disability were ruled out in the boy. Brain defects or intellectual disability are additionally present in Pfeiffer Syndrome [1]. In the proband no brain defects are detected. Perinatal complications or mental retardation during Pfeiffer Syndrome type 1 are a possible cause of the proband's intellectual disability.

Conclusion

The three presented persons are a rare discovery demonstrating the existence of variations of clinical expressions of the Pfeiffer Syndrome phenotype. The boy's intellectual disability and the clinical features observed in the examination of the family required careful individual analysis. The p.P252R mutation of the FGFRl gene occurring in the family is one of the most frequently found in Pfeiffer Syndrome. Identification of the genetic defect enabled comprehensive genetic counseling.

\section{REFERENCES}

[1] Vogels A., Fryns J. P.: Pfeiffer syndrome. Orphanet J Rare Dis. 2006; 1: 19.

[2] Cohen M. M.: Pfeiffer syndrome update, clinical subtypes, and guidelines for differential diagnosis. Am J Med Genet. 1993; 45: 300-307.

[3] Hackett A., Rowe L.: FGFR1 Pfeiffer syndrome without craniosynostosis: an additional case report. Clin Dysmorphol. 2006; 15: 207-210.

[4] Chokdeemboon C., Mahatumarat C., Rojvachiranonda N., et al.: FGFR1 and FGFR2 mutations in Pfeiffer syndrome. J Craniofac Surg. 2013; 24 150-152.

[5] Robin N. H., Falk M. J., Haldeman-Englert C. R.: FGFR-Related Craniosynostosis Syndromes. 1998 [updated 2011]. [w:] Pagon R. A., Adam M. P., Ardinger H. H., et al.: GeneReviews [Internet]. Seattle (WA): University of Washington, Seattle; 1993-2015. Address: http://www. ncbi.nlm.nih.gov/books/NBK1455/.

[6] Jakubiuk-Tomaszuk A., Boćkowski L., Sobaniec W., et al.: Opis przypadku 15-letniej dziewczynki z zespołem Aperta. Neurol Dziec 2012; 21, 42: 69-72.

[7] Jakubiuk-Tomaszuk A., Boćkowski L. Sobaniec W., et al.: Padaczka w zespole Aperta - opis przypadku. Neurol Dziec 2012; 21, 42: 73-77.

[8] Rossi M., Jones R. L., Norbury G., et al.: The appearance of the feet in Pfeiffer syndrome caused by FGFR1 P252R mutation. Clin Dysmorphol 2003; 12: 269-274.

[9] Saldino R. M., Steinbach H. L., Epstein C. J.: Familial acrocephalosyndactyly (Pfeiffer syndrome). Am J Roentgenol Radium Ther Nucl Med. 1972; 116: 609-622.

[10] Roscioli T., Flanagan S., Kumar P., et al.: Clinical findings in a patient with FGFR1 P252R mutation and comparison with the literature. Am J Med Genet. 2000; 93: 22-28. 